\title{
Demographic Development of the Ingrian National Minority in Estonia
}

\author{
KALEV KATUS, Ph.D., Professor and Director \\ ALLAN PUUR, Ph.D., Researcher \\ ASTA PÕLDMA, M.A., Researcher \\ Estonian Interuniversity Population Research Centre, \\ Tallinn, Estonia
}

\section{Abstract}

The article focuses on the demographic development of the Ingrian minority in Estonia. In a broader framework the research underlying the article originates from a comparative study of national minority populations, coordinated by the European Population Committee. The article starts with a short overview of major changes in the ethnic composition of the Estonian population, covering the implications of the Second World War on national minorities and the emergence of a foreign-origin population. The analysis of the Ingrian minority draws on the data from the Estonian national minority survey. Building on the life course approach and event history methodology, the survey was designed to retrospectively reconstruct the trends in major demographic processes and follow the continuity of minority-specific characteristics across three successive generations. The article discusses the size and age structure of the Ingrian population, fertility and mortality patterns, ethnic intermarriage, language and religious affiliation. The results emphasize that national minority populations tend to follow distinct pathways of population development, which are different, from the patterns characteristic of the majority population as well as from those found in the countries of historical origin. Also, the analysis clearly revealed long-term consequences imposed by the loss of their homeland and their dispersal.

Keywords: national minorities, Ingrians, language, religious affiliation, Estonia

The national minorities and the issues of ethnicity have been directly affected by the major societal discontinuity which hit Estonia in the middle of the 20th century. Among the multiple implications of geopolitical change that accompanied the Second World War, the national statistical system was dismantled and replaced by a subordinate branch charged with the implementation of instructions from outside the country. The results of the discontinuity have been particularly disruptive when it comes to the

\footnotetext{
The article has been prepared in the framework of the research theme $0501463 \mathrm{~s} 00$ and supported by the
} ETF grant No.2801. 
statistics on national minorities. Population characteristics essential for the consistent identification of minority populations were dropped from censuses and vital statistics, and the new concepts introduced lacked comparability over time and space. Needless to say, these developments were in sharp contrast with the extent of transformation that occurred in the population composition - Estonia lost most of its national minorities, but on the other hand, in relative terms the country gained one of the largest immigrant populations in Europe.

Over the past decade, population science in Estonia has targeted considerable efforts towards closing the gaps in the country's demographic time series and developing an internationally comparable basis for research. With respect to national minorities and foreign-origin population, these efforts have been undertaken in liaison with the comparative research program of the European Population Committee. Along with eight other countries representing different regions of Europe, Estonia participated in the study which addressed the long-term development of national minorities since the beginning of the 20th century. In addition to generalizing trends and patterns across Europe, the study made a noticeable methodological contribution to the conceptualization and measurement of national minorities, on one hand, and ethnically diverse foreign-origin populations which have emerged during the postwar period, on the other hand (Haug, Compton and Courbage 1999-2000; 2002).

Related to the national project in the framework EPC study, the present article focuses on the demographic development of the Ingrian national minority in Estonia. In the broader framework, Ingrians in Estonia represent an interesting case combining - due to historical circumstances - the features of both a national minority and an immigrant population. Due to the discontinuity of the national statistical system, the information on Ingrians available from traditional sources of demographic information, the census and vital statistics, has been extremely scarce. Apart from the latter, the article draws on the data from a specially designed linkage survey, applying event history methodology for the reconstruction of demographic trends among national minorities. Before addressing the main theme of the article, however, the article starts with a concise overview of major changes in the ethnic composition of the Estonian population.

\section{Long-term development of national minorities and the emergence of foreign-origin population}

\section{National minorities until the Second World War}

Throughout the centuries Estonia has been a home for national minorities who have settled in the country in different periods and under varying historical circumstances. The modern boundaries of Estonia were defined in the Tartu Peace Treaty (1920) with Soviet Russia and by international agreements with Latvia, following the principle of 
ethnic territory. Within these boundaries, the country had five national minority populations, each of which featured a specific settlement history as well as a distinct demographic profile (Katus, Puur and Sakkeus 1997).

Russians became a neighboring nation to the Estonians around the 10th century; however, the Russian settlement in the modern territory (in the border regions of Southeast Estonia, mostly Petserimaa) dates back to the much later period of the Livonic War in the 16th century. During the early 18 th century, new settlements of Russian peasants and fishermen were established at Lake Peipsi by old-believers who were escaping from religious oppression at home (Grass 1914; Moora 1964). Although the Baltic provinces became a part of the Russian Empire in the early 18th century, there was no significant Russian immigration for more than 150 years. The situation started to change with the large-scale Russification program introduced by Alexander III in the $1880 \mathrm{~s}$. Immigration increased significantly, contributing to the growth of the urban strata among the Russian national minority in the country.

The rapid growth of the Russian minority continued at the beginning of the 20th century and accelerated in the years preceding the outbreak of the First World War. The turning fortunes of the war, however, led to the evacuation of Russian administrators, industrial and military personnel and the size of the minority population sharply decreased during the German occupation. Yet another fluctuation in the number of Russians was introduced by the wave of refugees from Red Russia, most of whom moved further on to other countries.

Germans entered Estonia in the early 13th century as invaders, and following the conquest, established themselves as a ruling class in the Baltic provinces (Wittram 1973). The number of Germans remained rather small, never five to six percent of the total population. There was never any significant immigration by the German peasantry, and the limited influx of merchants and craftsmen to the cities was relatively unimportant due to the low proportion of urban population throughout the period. To this end it is important to note that during almost seven hundred years being German in Estonia did not have a distinct ethnic connotation but rather implied an affiliation to the upper social strata - if persons from the local population were to be upwardly mobile they became Germans. In fact, for the German minority this upward social mobility was the main source of accretion. In the 19th century when the modern concepts of nation and ethnicity gained ground, the Baltic-Germans began to transform into a national minority. Most importantly, this meant the cessation of the assimilation process which had earlier accompanied social mobility. Together with the emigration of Germans, directed mainly towards St. Petersburg and other major urban centers of the Russian Empire but also to Germany, the cessation of social mobility lead to the steady decline of the German minority in the last decades of the 19th century. Nonetheless, despite their relatively small and declining number, the Germans maintained their ruling social position up to the First World War. 
The emergence of the Swedish minority in Estonia dates back to the 13th and 14th centuries (Blumfeldt 1961). Swedish fishermen formed an area of compact settlement on the small islands off the northwest coast, several of which had previously been uninhabited. From the social viewpoint, Swedish settlers belonged mainly to the peasant class, and even during the period of Swedish rule between 1561 and 1710, a distinct Swedish upper class did not emerge. In addition, a small Swedish minority could be found also in the urban settlements of Northern Estonia, mainly Tallinn (Veispak 1986). In terms of spatial distribution it is important to note that in addition to Russians, the Swedes were the only national minority which had their own compact settlement areas - altogether there were four communities with a Swedish majority in Estonia prior to the Second World War. About 70 percent of the Swedes resided in Läänemaa County where they accounted for seven percent of the total population.

Together with Livs who inhabited the coastal areas of Vidzeme, Latvians have for long been a neighboring nation to the Estonians in the south. The extension of the Latvian settlement westwards, towards the coast, intensified after the Livonic War in the 16th century and step by step, a Latvian and Estonian contact area was formed along the entire southern border. In contrast to the border with Russia, however, no major areas of mixed population developed between the two countries (Palli 1996). The modern Latvian minority in Estonia was defined only when the national boundaries were set in the 1920s. As the new boundaries followed the principle of ethnic territory, only a small and dispersed Latvian national minority was left in Estonia even in the communities bordering their country, the proportion of Latvians did not significantly exceed one-tenth of the population.

The Jewish community in Estonia only began to form in the middle of the 19th century (Gurin 1936). It began after a special law was promulgated by Alexander II in 1865 which allowed certain strata of Jews to settle in the northern part of the Russian Empire (soldiers, merchants, craftsmen and professionals with a higher education). The process intensified during the reign of Alexander III when anti-Jewish pogroms were introduced in Ukraine and Belorussia; however, the volume of immigration appeared fairly limited.

Table 1. Size of national minority populations. Estonia 1934.

\begin{tabular}{lcc}
\hline $\begin{array}{l}\text { National } \\
\text { minority }\end{array}$ & Number & $\begin{array}{c}\text { \% in total } \\
\text { population }\end{array}$ \\
\hline Russian & 92,656 & 9.2 \\
German & 16,346 & 1.6 \\
Swedish & 7,641 & 0.7 \\
Jewish & 4,434 & 0.4 \\
Latvian & 5,435 & 0.5 \\
\hline
\end{tabular}

Source: 1934 census. 
According to the last pre-war census taken in 1934, Estonians comprised 88.1 percent of the total population. Among the remainder, the Russian national minority made up the biggest group accounting for 92,600 or 9.2 percent. Germans formed the second largest minority, followed by Swedes, Latvians and Jews (Table 1). All other ethnic groups - altogether more than fifty - accounted for 7,300 individuals. The size of these groups, however, appeared far too small to maintain continuity across generations and be considered a national minority.

In political terms, national minority populations in Estonia were officially recognized and eligible for state support. Special legal provisions for national minorities became a part of the Constitution and the law governing the rights and organization of national minorities (the Cultural Autonomy Law) was passed in 1925 (Riigi Teataja 1925). As Estonia was the first country in Europe to adopt the principles and policies of cultural autonomy, the corresponding practice attracted considerable international attention at the time (Hasselblatt 1928; Schiemann 1937). Among others, the specific Estonian legislation was discussed in and recognized by the League of Nations. The policies were also appreciated by the minorities themselves, and for example in 1926, after granting rights to the Jewish minority, Estonia became the first government to be recognized in the Golden Book of the Jewish National Fund (Loov-Gurin 1990).

\section{Implications of the geopolitical rearrangement and the emergence of the Ingrian national minority}

The Second World War deprived Estonia of its sovereignty and left the country under the will of opposing great powers, a position which, as it turned out later, lasted for more than fifty years. Due to the war and related societal discontinuity, the population of Estonia suffered heavy losses. Together with Latvia, the country belongs to the few European nations which have not recovered in numbers: the native population forms about nine-tenths of its pre-war size (Katus 1990). Against that background, however, disproportionate losses occurred to national minorities.

With the Molotov-Ribbentrop Pact, which divided Central and Eastern Europe between the two expansionistic powers, it was agreed that the German minority could leave the countries that were expected to go under Soviet rule, including Estonia. Repatriation was initiated in October 1939, and by May 1940, about 80 percent of the Germans had left the country (Hehn 1982). The remaining 20 percent refused to go; however, the occupation of Estonia by the Soviet Union changed their attitude decisively (Angelus 1995). Those few Germans who stayed in the country were arrested and deported in 1945, and as a result, no German presence was left in Estonia for the first time in 700 years (Figure 1). 
Figure 1. Dynamics of national minorities. Estonia 1934-1945.

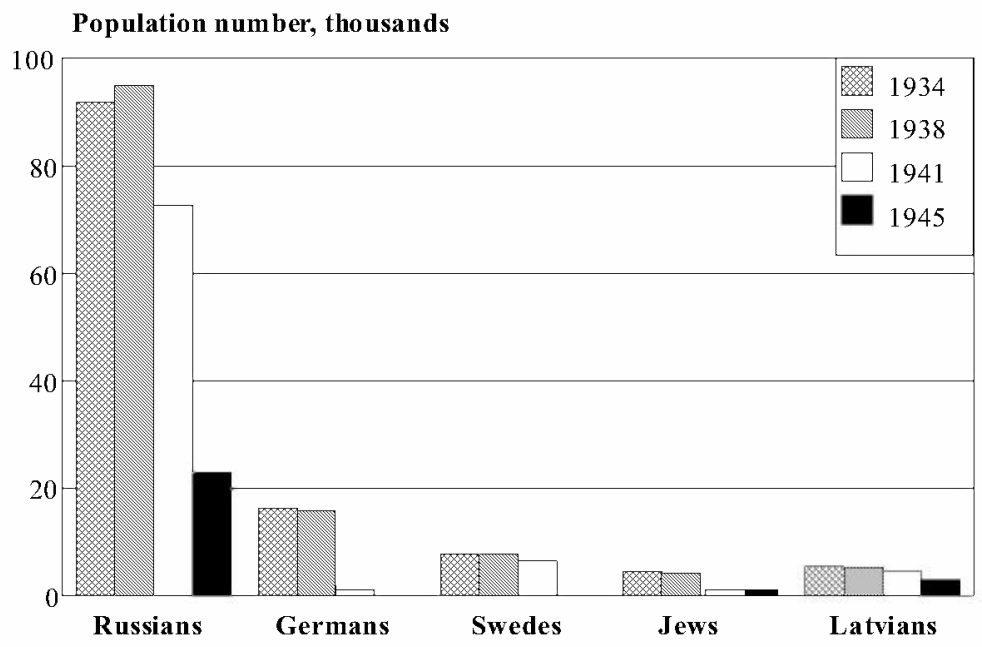

Source: 1934 \& 1941 censuses, Kaufmann 1967.

Losses of the Jewish minority, like the population of Estonia in general, started during the first Soviet occupation. The mass deportation in June 1941 accounted for nearly 10 percent of their number, and was a significantly higher proportion than for the total population (Salo 1993). At the beginning of the German-Soviet war, Jews were given a possibility to escape to the rear of the Soviet Union. Most of them used the opportunity and it has been estimated that only around one thousand remained in Estonia (Loov-Gurin 1994). Nazi authorities closed Jews in Estonia into concentration camps and by July 1, 1942, Estonia was declared to be Judenfrei. After the war, part of the Estonian Jews returned but the available data suggests that this amounted to no more than 15-20 percent of the pre-war number (about one thousand). Due to their small size, the remaining Jewish population could not maintain its continuity on previous terms.

In 1940 Sweden took steps to get permission for the Swedish minority in Estonia to leave, however, in practice repatriation was not implemented. The issue came on the agenda again in 1944 when the threat of a second Soviet occupation emerged. This time Sweden negotiated with the German authorities, and despite the opposition of the German Foreign Ministry, an agreement was reached with the local German military command (Kommitten... 1950). The Swedish minority lists were prepared according to the principles of the Cultural Autonomy Law, in addition to Swedes also many Estonians again managed to be included on the lists and fled from the country (Aman 1961). As a result of this organized repatriation, the Swedish minority in Estonia virtually ceased to exist. Together with a part of the returnees among those mobilized and deported by the Soviet authorities in 1940-1941, the number of Swedes in Estonia hardly exceeded a couple of hundred by 1945. 
The Latvian minority had been one of the smallest and the most integrated already in the 1920s-1930s, largely as a result of mixed marriages. The trend towards assimilation was strengthened by the sharp decrease in the number of Latvians by the transfer of Petseri County to the Russian Federation in 1944. Together with the deportations, repressions and war operations, the transfer at least halved the number of the Latvian minority, leaving the remainder dispersed throughout the country. Given these circumstances, Latvians progressed towards the end of their status as a national minority.

In regard to the Russian national minority, the first Soviet occupation hit those most heavily who had entered Estonia earlier as refugees. The deportations and other acts of repression are estimated to have accounted for one-third of that strata. The next, much sharper decrease of the Russian national minority occurred in 1944 when the Supreme Council of the Soviet Union unilaterally established the new boundaries, transferring most of Petseri County (August) and the Trans-Narva areas (November) from Estonia to the Russian Federation. As a result, Estonia lost nearly all its mixed population regions. From the demographic perspective, the transfer of Petseri County and the Trans-Narva areas to the Russian Federation implied the reduction of the population by 66,500 according to the 1934 census and by 56,200 according to the population estimates for 1944 (Kaufmann 1967). In the new boundaries the Russian minority in Estonia amounted to about 23,000 (Katus 1990). Although reduced by more than three-fourths from its pre-war size, the Russians were the only population group which maintained its existence as a national minority in Estonia.

Against the background of the disappearance or marked reduction of national minorities, Ingrians - another historical neighbor of the Estonians - represent an opposite case. Historically, Ingria was a landbridge between Estonia and Finland and the contact area for three Finno-Ugric nations: the Isurs, Votians and Estonians (Kurs 1994). In the 12th century, Ingria fell under the rule of Novgorod as the 'Votian Fifth' and was converted to the Orthodox faith. After the conquest of Novgorod by the Muscovites, Ingria was included in Muscovite Russia and devastated by repeated deportations, followed by colonization and repopulation. When Ingria fell under Swedish rule at the beginning of the 17th century, immigration was encouraged into the severely depopulated country. The new settlers came mainly from Lutheran Finland (neighboring Estonia had also suffered a heavy population crisis). The turning point in the history of the country came with the Nordic War, which led to the reincorporation of Ingria into Russia. The new imperial capital was founded on Ingrian territory and the whole country renamed St.Petersburg Gubernia. The gradual repopulation of Ingria was completed in the 20th century - before the First World War, the number of Ingrians amounted to more than 200,000 , but had dropped to 176,000 by the 1926 census and to 16,800 by the 1989 enumeration (TsSK 1905; TsSK 1928; Goskomstat 1990). 
Under Soviet rule, Ingrians suffered heavily from the liquidation of farm-based agriculture, the closing of the national schools, other organizations and the Lutheran Church. These measures were accompanied by mass repression and deportations which started in the late 1920s and reached a climax in 1937. During the Second World War, Ingria became a theater of war for three years and a number of Ingrians were evacuated to Estonia. In 1944, this was followed by the organized evacuation of more than 60,000 Ingrians to Finland via Estonia (Kurs 1994). According to the terms of the FinnishSoviet peace treaty, as Soviet citizens, the Ingrians were then returned to the Soviet Union but rather than being allowed to return to their homeland they were relocated in other areas. It was only after 1956 that they were permitted to leave the areas of deportation, but since there were still restrictions on their return to Ingria, many came to live in Estonia.

Although the late formation of Ingrians in Estonia implies several features which are characteristic to foreign-origin population, geographical position, long-established historical contacts with Estonia, similarity of language and culture speaks for the inclusion of Ingrians among national minorities rather than among the outcomes of postwar immigration.

\section{Foreign-origin population and the transformation of ethnic composition}

In the postwar period, the transformation of the ethnic composition of the population has been determined by migration processes. Over the long run, the development of migration processes in Estonia fits well into the concept of mobility transition, developed by Wilbur Zelinsky (1971). Following the onset of demographic transition in the middle of the 19th century, with some time-lag the country entered the stage of sharply increased spatial mobility at the end of the century. During that stage, the acceleration of population growth brought about the increase in migration potential which resulted in internal urbanization, relatively modest in the comparative European perspective, and emigration from the ethnic territory, which appeared to be quite intensive.

Regarding emigration, a characteristic feature of Estonia in the context of contemporary emigration flows from Europe was its direction towards the East. The majority of emigrants from Estonia were settled in neighboring regions like Ingria, the Russian provinces of Pskov and Vitebsk and the city of St.Petersburg (Arens 1994; Moora 1964; Pullat 1981). The destinations of long-distance emigrants were the sparsely populated frontiers of the Russian Empire (Nigol 1918). In total, the number of Estonians living outside the ethnic borders but within the Russian Empire can be estimated at approximately 200,000 before the First World War - about 20 percent of the total number of Estonians (Katus 1990). The establishment of the Estonian Republic coincided with the emerging decrease of migration potential and the 1920s marked a gradual cessation of emigration. Following the First World War, the remaining migration potential was almost completely redirected to the development of an urban settlement 
system in Estonia. International migration remained at very low levels, with the first signs of forthcoming labor immigration.

Figure 2. International migration flows. Estonia 1946-1999.

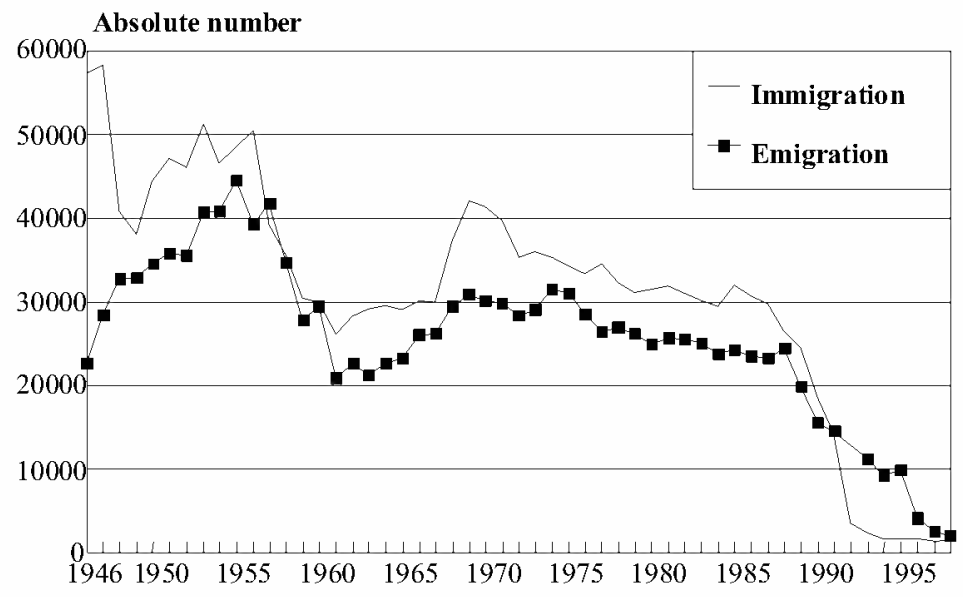

Source: annual migration statistics.

After the Second World War, Estonia, like other European countries in early demographic transition, experienced a turn from an emigration to an immigration country. For several reasons this change occurred about a decade earlier and proved to be particularly abrupt in Estonia. The key to understanding the postwar migration processes lies in the timing of demographic development, similarly to the late 19thearly 20 th century when Estonia was a receiving country. By the 1940s Russia as well as other Slavic republics had entered the stage of mobility transition and reached the peak of their migration potential. The high potential was partly directed to the newly incorporated territories, including Estonia. Immigration was further strengthened by the huge difference in the scale of sending and receiving populations, de facto elimination of the national borders between Estonia and Russia, administrative stimulation of immigration, extensive losses of native population etc. (Misiunas and Taagepera 1983; 1993). From the demographic point of view, however, the decisive contribution was made by the advanced stage of population development which implied very limited or even negative growth of the native population already from the early postwar decades.

The trend of Estonia's international migration included two major waves in the postwar period (Sakkeus 1996). The first wave occurred in the immediate postwar decade with the highest immigration flows ever recorded in the country (Figure 2). Following the change in the political regime in the mid-1950s, the immigration flows decreased. The decrease of immigration resonated with the emerging reduction of migration po- 
tential in the regions of departure, but also the cessation of administratively-directed migration made its contribution. The new increase of immigration occurred in the late 1960s. The emergence of the second wave of immigration as well as the relatively high migration volumes up to the dissolution of the Soviet Union reflect the enlargement of the migration hinterland. While the first wave of immigration originated mainly from the neighboring regions of Russia, by the 1970s the hinterland had expanded towards more distant regions (including the lower reaches of the Volga, North- and Trans-Caucasia, Central Asia) with a later timing of the demographic transition and sustained migration potential. In relative terms, the first immigration wave comprised only one-fourth of the total immigrants while three-fourths originated from the hinterland after its expansion (Figure 3).

Figure 3. Country of origin of foreign-born population, $\%$.

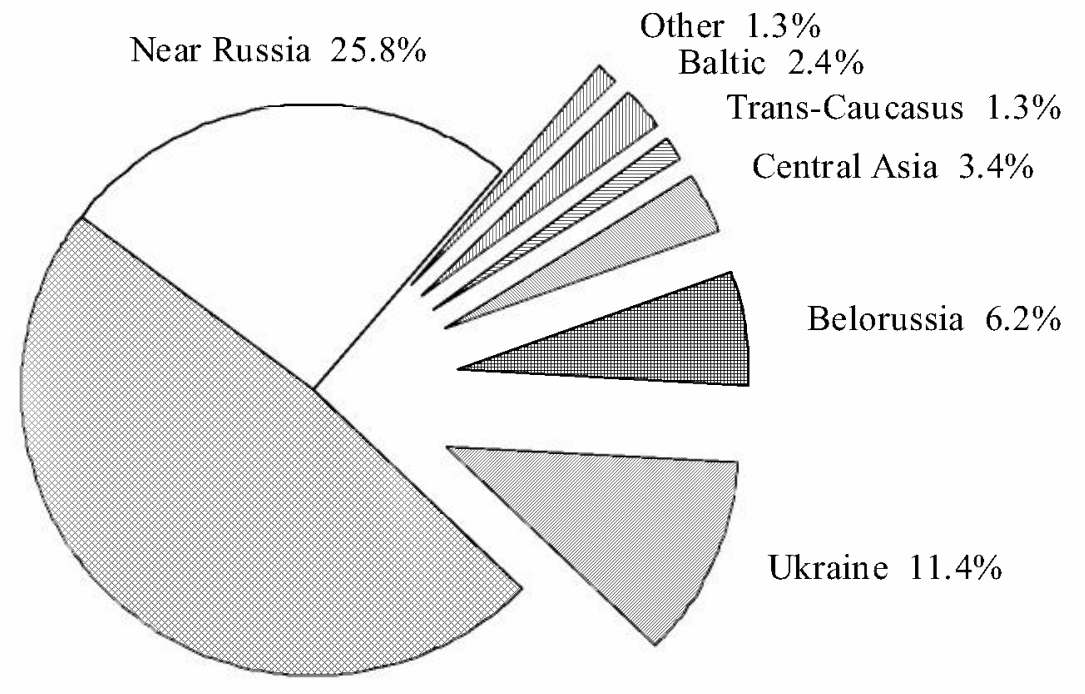

Russia $48.1 \%$

Source: 1989 census.

Following the restoration of statehood, international migration flows sharply decreased showing even negative net-migration in the early 1990s. Even though intensive immigration has passed, immigration has left Estonia with an extremely sizeable stock of foreign-origin population (Table 2$)^{1}$. By the late 1980 s, the proportion of foreignorigin population reached 36 percent of the total population of Estonia, which is one of the highest in the European context. Taking only the first generation of immigrants,

${ }^{1}$ For the pre-war period, the number of foreigners can be directly drawn from the official statistics. Regarding the postwar period, the corresponding numbers for 1959-1979 are estimates as these censuses lacked the place of birth/origin in their programs. Nonetheless, based on the combination of population characteristics such as migration status, ethnicity and family/household, the estimates can be drawn with relatively high accuracy. 
i.e. the foreign-born, their proportion in Estonia (26 percent) closely follows Luxembourg, exceeding, for example, the corresponding figures in Latvia and Switzerland, and being almost three times higher than in countries like Germany, Austria and Belgium (Council of Europe 1993-2001).

Table 2. Native and foreign-origin population* in Estonia** (excluding the military occupation forces).

\begin{tabular}{cccc}
\hline Census & $\begin{array}{c}\text { Total } \\
\text { population }\end{array}$ & $\begin{array}{c}\text { Native } \\
\text { population }\end{array}$ & $\begin{array}{c}\text { Foreign-origin } \\
\text { population }\end{array}$ \\
\hline 1922 & $1,107,100$ & $1,082,300$ & 24,800 \\
1934 & $1,126,400$ & $1,114,200$ & 12,200 \\
1941 & 999,900 & 999,900 &.. \\
$1945^{\mathrm{a}}$ & 854,000 & 854,000 &.${ }_{\mathrm{b}}$ \\
1959 & $1,196,800$ & 944,900 & 251,900 \\
1970 & $1,356,100$ & 990,300 & 365,800 \\
1979 & $1,464,500$ & $1,013,800$ & 450,700 \\
1989 & $1,565,700$ & $1,029,800$ & 535,900 \\
& $1,370,500{ }^{\mathrm{c}}$ & $?$ & $?$ \\
2000 & $1,439,200$ & & \\
& & & \\
\hline
\end{tabular}

\footnotetext{
*Figures presented in this table result from the harmonisation of and should be regarded as estimates.

** From 1945 the territory of Estonian SSR; $2334 \mathrm{~km}^{2}$ less than the territory of Estonian Republic.

a Estimate 1.1.1945.

b Number is neglible from the viewpoint of population development

${ }^{c}$ ESA, estimate 1.01.2000.

d ESA, census 2000 .
}

The extremely high proportion of foreign-origin population, but even more importantly, the divergence of demographic development and social development requires careful consideration. Among European nations, Estonia and Russia feature one of the largest differences in the timing of demographic transition between neighbors (Katus 1990; Vishnevski and Volkov 1983). For that reason, the trends and patterns for the total population tend to be a misleading aggregate of two different, sometimes opposite components (e.g. Ahven 1998; Kasmel et al. 1997; Katus et al. 1999; Katus, Puur and Põldma 2002; Pavelson 1997). To an equal extent it is important to underline the distinction between foreign-origin population and national minorities. The expansion of the migration hinterland, as noted above, introduced a huge ethnic diversity in the foreign-origin population - population censuses have enumerated more than 120 different ethnic affiliations (Viikberg 1999). In terms of their characteristics as well as integration into the host society, however, these groups demonstrate patterns typically found in immigrant populations. The distinction from national minority populations has been directly revealed by the comparison of the Russian national minority, on one hand, and the immigrants of the same ethnic background on the other hand. The analyses undertaken in the framework Council of Europe study have shown systematic differences between the two in a broad range of demographic and social patterns (Katus, Puur and Sakkeus 2000; Sakkeus 2000). 
Over the long run, of course, part of today's immigrant population will transform into national minority population(s), integrated into the host society but at the same time retaining and developing their specific sociocultural identity. As the second generation of immigrants has until recently displayed relatively weak signs of integration, this transformation will likely require a considerable time to occur in Estonia. For the same reason, it is necessary to make a continuous distinction between the population groups referred to.

\section{The demographic development of the Ingrian national minority}

\section{Scope of the study, data sources and methods}

The Council of Europe study on national minorities addressed the demographic development of minority populations (Haug, Courbage and Compton 1991-2001). The study was commissioned by the CoE Committee of Ministers, as a part of efforts to foster the recognition of political, legal, socioeconomic and cultural rights of minority groups in Europe. Under the responsibility of the European Population Committee, detailed analyses were prepared on eight countries. The geographical scope included Bulgaria, Estonia, Finland, Hungary, Northern Ireland, Romania, the Slovak Republic and Switzerland.

The substantive focus of the study encompassed the main aspects of demographic development among national minority populations, including population number, geographical distribution and processes like fertility, mortality, nuptiality, divorciality, population aging etc. Another principal focus of interest was related to characteristics which are central in defining the national minorities and distinguishing them from majority populations. In particular the study emphasized the country of birth/origin, ethnic self-identification, language and religion. The time frame of the investigation covered most of the 20th century, stretching from the decade of the First World War up to the $1990 \mathrm{~s}$, and adding the outlook for the future. The principal aim of the analyses was to provide, on a comparative basis, a demographic account of what is known as a very complex and controversial topic. As regards the data, the study draws on all three main sources of population information - censuses, vital and survey statistics. Following the general practice of comparative studies under the European Population Committee, the program did not foresee the collection of primary data but rather the extensive use of existing information available in each country.

In the case of Estonia the discontinuity of the national statistical system did not allow tracing the development of the national minority populations in the period following the Second World War. Most importantly, the set of population characteristics required for consistent identification of national minority populations was not applied in that 
period. Reflecting the governing ideology which anticipated the fusion of the population into a unified Soviet nation, information on place/country of birth/origin was considered irrelevant and removed from census programs as well as from vital statistics. The same holds for religious affiliation which was regarded as a remnant of bourgeois society and accordingly omitted from official statistics. Individual ethnic identification was registered, however, and this characteristic was given a legal categorization and recorded in the individuals' passport. For the purposes of vital statistics, this legally determined ethnicity was used, which resulted in a noticeable discrepancy with population censuses based on self-declaration etc.

The only means of bridging the gap and securing consistent information on minority populations was through a specially designed linkage survey, Eesti Põlisusuuring (EPU). The principal aim of the survey was to reconstruct the main trends in the demographic development of national minorities in the postwar period. To meet this aim, the EPU program combined two elements. First, building on the life course approach the survey collected event history data on major life careers of the population (Blossfeld and Rohwer 1995; Willekens 1999). The questionnaire comprised complete histories on partnership formation and dissolution, fertility, migration and residential mobility, education and work, with event-oriented data also being collected on the parents of the respondents. This part of the EPU program was closely consistent with the Estonian Family and Fertility Survey which was undertaken as a national part in the framework of the European FFS, coordinated by the United Nations Economic Commission for Europe (EKDK 1995a; 1995b; UNECE 2002). In the EPU the individual life histories provided a basis for the retrospective reconstruction of the time series of demographic indicators.

Second, the EPU collected comprehensive information on characteristics relevant to the definition of minority populations (place/country of origin/birth, individual ethnic identification, usual language, religious affiliation). Minority-specific characteristics were traced through three successive generations, starting with the grandparents along both parental lines. The corresponding information was gathered also for the respondents' children and partners. Most importantly, this information was meant to support the analysis of the continuity of minority populations and the process of assimilation, including inter-generational and intra-generational changes in language, religious affiliation and citizenship.

The target population of the EPU was constituted of females of the Ingrian and the Russian national minorities born in 1924-1973. The life courses of these birth cohorts allowed coverage of the postwar period, and through the parental generation the data can partially be extended to the first half of the 20 th century. The microdata of the 1989 population census was applied as a sample frame; technically this was the only source supporting the sampling of national minorities. For both minority populations, a nationally representative probability sample aimed at about 140-150 completed in- 
terviews per five-year birth cohort. The fieldwork was accomplished in 1997 by the interviewer network of Statistics Estonia. Altogether 1,310 respondents of the Russian national minority and 1,481 respondents of the Ingrian national minority were interviewed. The general response rate was 85.6 percent. The fieldwork and related procedures of the EPU were merged with those of the male survey of the Estonian FFS. The national FFS working group was responsible for survey management. Detailed information on survey procedures can be found in the methodological report (EKDK 1999).

The following sections present the main findings from the EPU with respect to Ingrians. A survey cannot, of course, totally replace the lack of census and vital statistics on national minorities. In particular, it cannot supply the precise number of a national minority and related characteristics. Therefore, for the latter purpose, complementary data from the population census and vital registration are used, with corresponding references included in the text. As regards the aim of the analysis, this article is geared to giving a concise demographic outline of the Ingrian national minority in Estonia. Due to the discontinuity introduced into the statistical system, such an account which would systematically apply the population perspective has been missing so far and the analysis based on the EPU represents the first attempt along this road. For that reason, the article is not targeted at specific aspects of minority development but rather addresses general patterns. Such a broader focus is also essential for pointing out the directions for further research, supported by detailed life history data on the minority population.

More specifically the following sections deal with the number and age structure, fertility, mortality, ethnic intermarriage, language and religious affiliation of the Ingrian national minority. Analytical techniques applied belong to the toolbox of classical demographic analysis, both in the period and cohort perspective. Notes on specific analytical methods are included in corresponding sections. Across different topics, Ingrians are viewed against the background of the majority population in which respect the role of the FFS should be underlined. Additionally, selected comparisons with the Russian national minority and Finland are also provided.

\section{Population size and age structure}

Size has often been an issue of controversy in the study of national minority populations. On one hand, it is not a secret that states have at different times manipulated the true size of their national minorities for reasons of self-interest. This has most often taken the form of understating the size of minority populations, either because they have been viewed as a threat to national cohesion or to bolster arguments of a geopolitical nature. With respect to Ingrians, inaccuracies may have been generated by targeted repressions and discrimination. In Soviet practice, individual ethnic identification was given a legal categorization and recorded in the individual's passport. Under Stalin's 
regime, the authorities used these records against the individuals, which understandably may have generated disinterest to disclose one's affiliation to a national minority.

On the other hand, ambiguities concerning the size of national minorities are related to objective circumstances, including the patterns of ethnic intermarriage, bi- or multilingualism etc. Under such circumstances persons may experience affiliations to several groups simultaneously and the available statistical information may fall short in handling such situations with sufficient subtlety. This applies not only to Ingrians, as the statistical system introduced in Estonia after the Second World War did not aim at appropriate identification of national minorities as the governing ideology anticipated the fusion of all ethnic groups into one unified Soviet nation (Konstitutsija 1977; Stepanjan 1981; Carrére d'Encausse 1982).

Figure 4. Population size. Ingrians, birth cohorts 1953-1981.

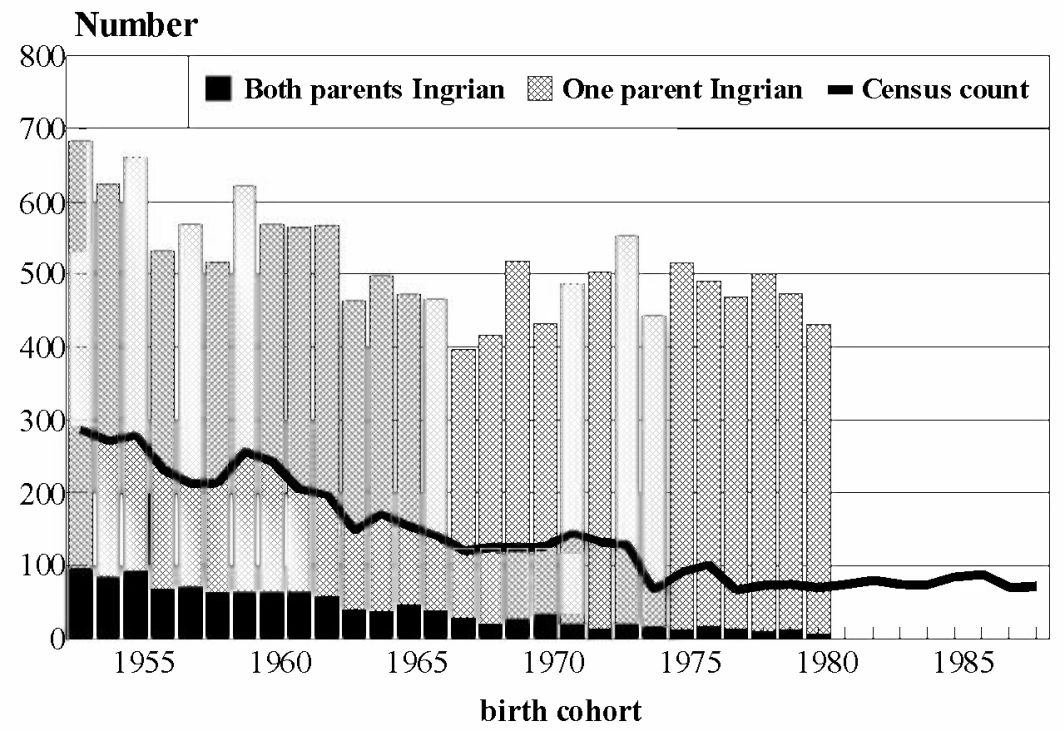

Source: 1989 census \& Estonian Fertility Databank.

Figure 4 presents the number of the Ingrian national minority based on census and vital statistics. To facilitate the comparison between the two sources, the data is organized by single-year cohorts. The data in the figure is derived from the Estonian Program for Population Data Comparability ${ }^{2}$. The census counts on Ingrians are based on

\footnotetext{
2 The program for the Estonian Program for Population Data Comparability aims at the reintroduction of international definitions and classifications, building time series and bridging the gap with pre-war statistics, securing the consistency of regional statistics and integrating vital, census and survey statistics. Accomplishing these tasks involves the harmonization of aggregate data, if available, recoding and reprocessing microdata, if it has endured, and computerization of archival records records, if aggregated and/or microdata is not available. The implementation of the Program has been until the present stage carried out by the Estonian Interuniversity Population Research Centre. Harmonized census, vital and survey statistics have been assembled in the Estonian Population Databank EKDK (1992a; 1992b).
} 
the microdata of the 1989 population census and refer to ethnic self-identification. Vital statistics data is drawn from the special subprogram for the harmonization of birth statistics and refers to the legal categorization of ethnicity. In that framework the individual-level birth records are retrospectively computerized, securing the consistency of data over time and space, and introducing internationally comparable definitions (EKDK 2003). The subprogram is being implemented in several stages, and by the time this article was prepared, the computerized birth records were available for the period 1953-1981. Although the data series does not cover the entire postwar period, it stretches across the periods with markedly different societal conditions.

A brief glance at the figure reveals a significant difference between the two sources. According to the census, the number of Ingrians accounts for nearly three hundred persons in the cohorts born in the early 1950s. In the following cohorts the number of Ingrians declines almost threefold, dropping below one hundred persons among those born in the mid-1970s. With respect to the following generations, born in the late 1970 s and 1980 s, the data reveals the discontinuation of the decline and stabilization of the number at noticeably low levels. Regarding the youngest cohorts it could be added that, according to census procedure, the answers on ethnic identification were usually obtained not from the children (under age 16) themselves but from the parents.

Vital records allowed producing two complementary estimates of the minority population - the number of births to families where both parents were Ingrians, including births to single mothers, and the number of births where at least one parent belonged to the minority population. It is evident from the graph that the number of births to Ingrian families along both parental lines has been very low (less than one hundred cases per annum) already from the beginning of the 1950s. In the following 15-20 years, the corresponding number decreased almost tenfold and reached about ten cases annually by the $1980 \mathrm{~s}$.

At the same time, however, the number of births to families with either the mother or father from the Ingrian minority has been not so small at all. Taken together, the annual number of births to Ingrian parents has accounted for more than 600 in the early $1950 \mathrm{~s}$. In relative terms, this translates into 3.5 percent of births registered in Estonia in that period. To this end one should also be reminded that due to the legal categorization of ethnicity in vital registration these figures are likely under- rather than overstated. By the late 1970 s and early 1980 s, when other estimates had fallen to very low levels, the number of births to families with at least one Ingrian parent still comprised $400-500$, i.e. more than two percent of the total. This proportion may seem quite small, but at the same time it clearly exceeds the corresponding percentage of German, Swedish, Jewish and Latvian national minorities (Katus et al. 1997).

The discrepancy between the presented estimates appears indeed very large, and moreover, it tends to increase towards the younger cohorts. According to census counts, the size of the Ingrian national minority has fluctuated between $16,600-18,500$ in the 
postwar decades. The estimates based on newly available vital records would put the total number of the Ingrian population at 35,000-37,000. Such an extensive discrepancy would be unthinkable for populations in the aggregate but with respect to national minorities it does necessarily signify faulty estimation. The results rather emphasize the decisive importance of definitions and measurement issues in the case of national minorities, at least when the size of the group and absolute numbers are concerned. In other words, it is not possible to distinguish between correct and erroneous estimates but definitions which represent different perspectives on minority populations. Although the study foresaw an attempt to integrate these perspectives, mapping the range of definition-dependent variation was perhaps more instructive than producing a harmonized demographic estimate (Katus et al. 2000).

Figure 5 presents the number of the Ingrian minority relative to the total population of Estonia, as reported by census data. The tabulation by single-year birth cohorts covering most of the 20th century clearly indicates sharp irregularities in the age structure of the Ingrians. The largest concentration of Ingrians (accounting for more than two percent of the corresponding total) can be found among the birth cohorts of the 1920s. Mostly this group had settled in Estonia in the aftermath of the Second World War, typically as returnees from deportation. For Ingrians, Estonia as well as Karelia became the most favored destinations primarily due to their geographic and cultural proximity to their lost homeland. Estonia also featured a better living standard, particularly prior to the forced collectivization of agriculture. Regionally, about three-quarters of the Ingrian minority became concentrated in four counties - Harjumaa (33.3 percent), Ida-Virumaa (20.8 percent), Lääne-Virumaa (10.9 percent) and Tartumaa (11.9 percent).

Figure 5. Proportion of Ingrians of the total population of Estonia. Birth cohorts. 1940-1989.

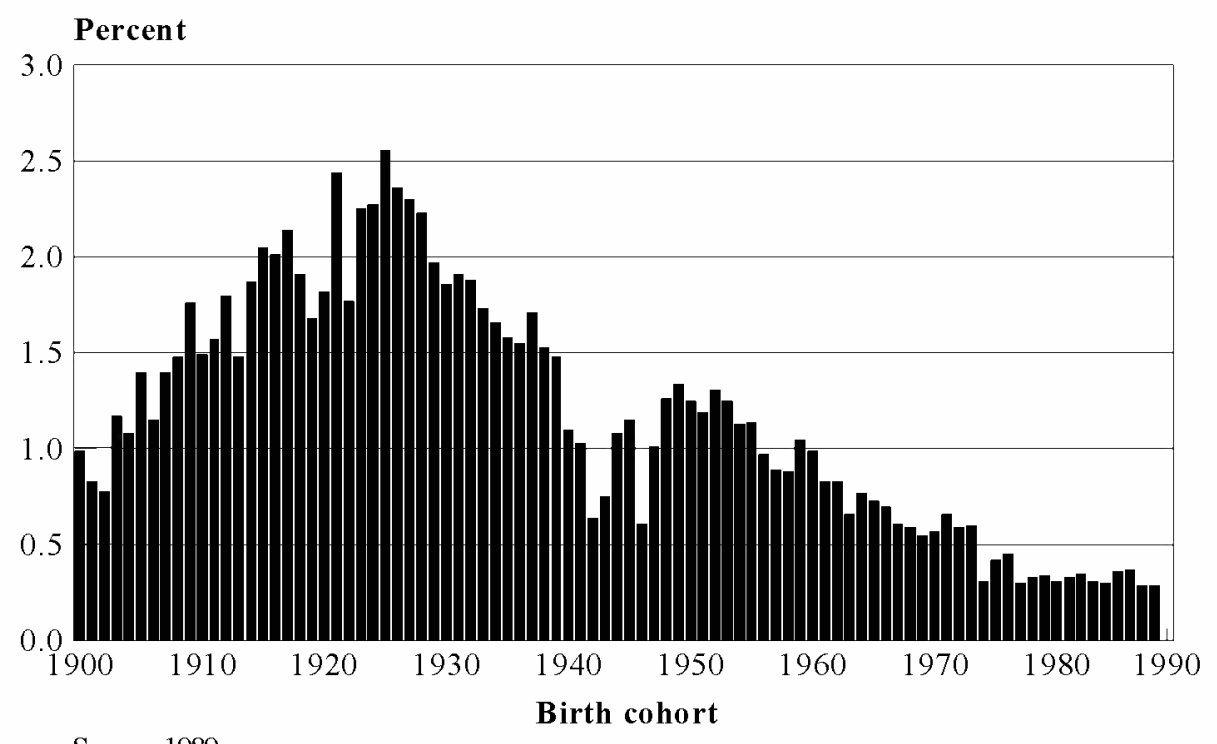

Source: 1989 census. 
When moving towards younger cohorts, the relative number of Ingrians steeply declines. In the birth cohorts of the 1940s, the age structure of the Ingrians embeds an extensive fertility decline during the Second World War. Reflecting the return of Ingrians from Finland to the Soviet Union, the age structure indicates a repeated fertility decline around 1946-1947. In contrast to the latter, the continuous decline in the younger cohorts cannot be explained by any demographic process but reflects a shift in ethnic self-identification and a marked tendency towards assimilation. Notably, this tendency can be followed in census as well as vital statistics, leaving no bright prospects for the future of the minority population.

Relying on President Koivisto's statement granting the Ingrians the status of return migrants, the number of Ingrians in Estonia decreased further in the 1990s. Data from the EPU suggests that more than four thousand Ingrians have left Estonia in the first half of the decade. This is somewhat higher than the figure given in Estonian official migration statistics but is somewhat lower than that indicated by Finnish sources (Kyntäjä 1997). The detailed analysis of these recent changes, however, goes beyond the aims of the present article.

\section{Fertility development}

The early beginning as well as relatively high regional homogeneity of the fertility transition in Estonia provides the general context within which the fertility trends for national minorities should be assessed. To cast light on the fertility of the Ingrians, the time series of the total fertility rate were reconstructed from the birth histories of EPU respondents (Figure 6). Although the fertility level has been relatively close to that of Estonians, one can also notice clear differences in Ingrian fertility compared to the majority population.

According to the reconstructed series of the total fertility rate Ingrians featured systematically higher fertility than Estonians until the 1960s. Evidently, this difference stems from a certain time-lag in the timing of the fertility transition between Estonia and Ingria. In Estonia, the fertility transition can be traced back to the middle of the 19th century and a continuous decline of fertility rates could be observed from the $1850 \mathrm{~s}-1860 \mathrm{~s}$. The Estonian population dropped below replacement fertility already by the late 1920s and the corresponding levels were maintained until the end of the late 1960s. In other words, if one had longer time series available, one would have probably seen much larger differences in fertility levels during earlier decades.

Another reason that contributes to the difference is the absence of a postwar baby boom in Estonia, a rather unusual phenomenon among the pioneering nations of the fertility transition. Figure 6 reveals that the TFR curve of Estonians is almost flat until the increase during the late 1960 s, which took fertility back to replacement level. In contrast to the Estonians, Ingrians seem to have experienced an increase in fertility in 
the second half of the 1950 s when societal conditions started to normalize. In the following decade fertility trends among Ingrians and the majority population diverged - instead of an increase Ingrians featured a gradual reduction in their fertility level. As a result of opposing trends, the mutual position of the two populations changed: starting from the early 1970s a higher fertility level became characteristic of Estonians. In the 1990 s, of course, the sharp and extensive fertility decline overshadowed virtually all differences between the population groups.

Figure 6. Total period fertility rate. Ingrians and Estonians 1940-1994.

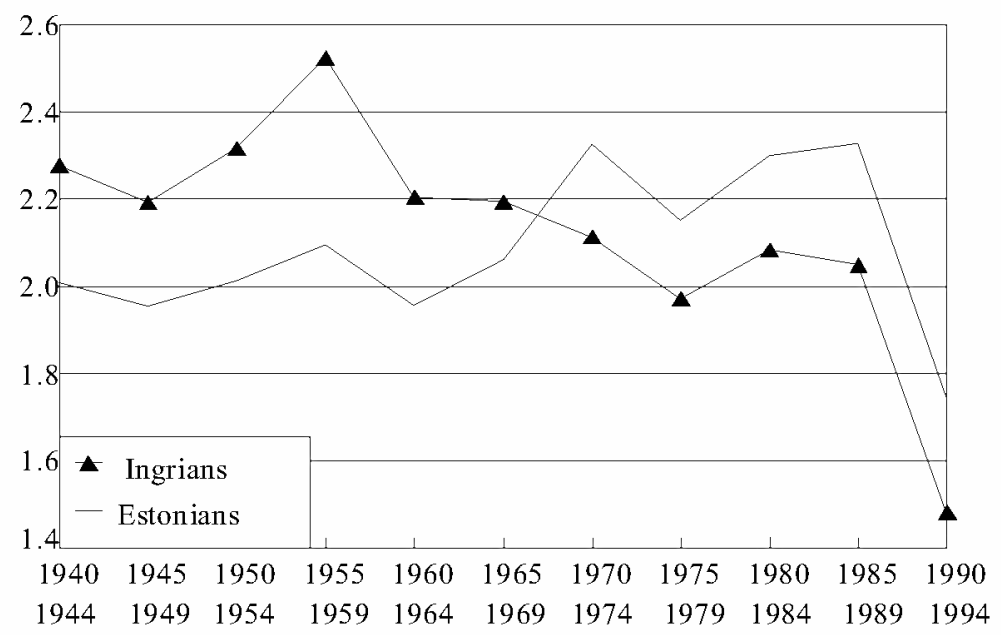

Source: authors' calculations, EPU \& EFFS.

It is instructive to compare the reconstructed fertility trend of the national minority with that in the corresponding titular country, i.e. Finland (Notkola 1989; Council of Europe 2001). In the late 1930s and early 1940s the fertility levels seemed to be close to each other but subsequently diverged. Like most of the European nations with low fertility before the Second World War, Finland experienced a marked postwar babyboom (Festy 1984; Sardon and Calot 1997). No such trend, however, emerged among the Ingrians if the limited rise in fertility during the mid-1950s, at the end of their forced displacement, is disregarded (Figure 7 on next page). Subsequently, Ingrian fertility has followed a declining trend but this was even sharper in Finland during the $1950 \mathrm{~s}-1960 \mathrm{~s}$, with the result that Ingrian fertility exceeded the level in Finland during the next twenty years. Following the sharp decrease in fertility during the 1990s in Estonia, the pattern became reversed.

The analysis of the EPU survey also revealed systematic differences in other aspects of fertility behavior, including the timing of childbearing, parity distribution and the connection between marriage and childbearing. Regarding timing, for example, Ingrians have shared the prolonged juvenation of fertility which has followed the disappearance 
of the European marriage pattern. Throughout the entire period under consideration, however, they have featured an earlier start of childbearing compared to Estonians the difference in the median age at first birth accounts for about one year. Also, Ingrians have had a somewhat lower proportion of extramarital births than Estonians, who have demonstrated levels quite similar to those found in Scandinavian countries (Katus et al. 2002).

Figure 7. Total period fertility rate. Ingrians and Finland 1940-1994.

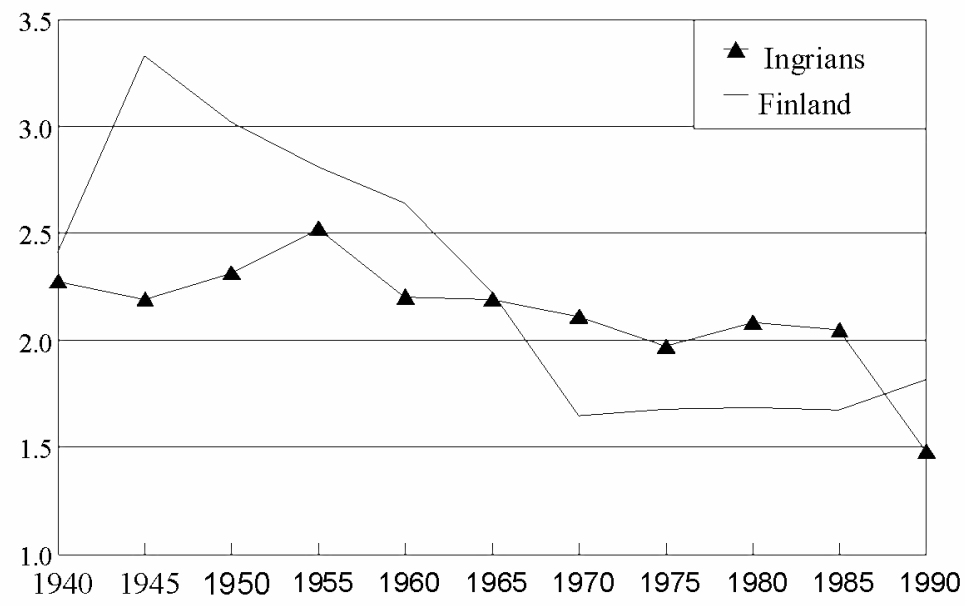

Source: authors' calculations, EPU \& StatisticalYearbooks of Finland.

The results indicate that national minority populations tend to follow distinct patterns of demographic development, which are different, on one hand, from those characteristic of the majority population, and on the other hand, also from the patterns found in the countries of historical origin. To this end it is interesting to note that apart from national minorities, among foreign-origin population in Estonia the trends have proven consistent with the developments in home countries (Sakkeus 2000).

\section{Mortality development}

Although the EPU provided relatively limited information on mortality, it was possible to estimate the levels of infant/child and adult mortality from the survey. In particular, the estimates of death probabilities were derived from the data on the survival of the respondent's siblings included in the parental-home module. Infant and child mortality, measured here as the proportion dying under the age of one and under 15 , were estimated for three broad birth cohorts: 1920-1939, 1940-1959, and 1960-1979.

Against the background of Estonians, the analysis showed consistently higher mortality levels among the Ingrian minority. In the cohorts born before 1960, the infant and child mortality of Ingrians appeared particularly high, exceeding the level of the majority population by $40-50$ percent (Table 3 ). Such a high mortality of Ingrians reflects the impact of particularly harsh societal conditions. The survey provided 
detailed information on how these circumstances affected the childhood conditions of different birth cohorts, including the experience of repressions, deportations and forced migration, loss of parents etc.

Table 3. Infant and child mortality. Birth cohorts 1920-1979.

\begin{tabular}{lcc}
\hline \multicolumn{1}{c}{ Cohort } & Ingerians & Estonians \\
\hline $\begin{array}{l}\text { Death probability until age 1 } \\
1920-1939\end{array}$ & 0.0816 & 0.0523 \\
$1940-1959$ & 0.0708 & 0.0509 \\
$1960-1979$ & 0.0265 & 0.0167 \\
Death probability until age 15 & & \\
$1920-1939$ & 0.1799 & 0.1093 \\
$1940-1959$ & 0.1234 & 0.0708 \\
$1960-1979$ & 0.0371 & 0.0259 \\
\hline
\end{tabular}

Source: authors' calculations, EPU.

The pattern of adult mortality has been estimated from the joint survival of generations, using the information on the survival of parents until the 14th birthday of their children (Figure 8 on next page). This approximates the adult survivorship in the ages up to 50, conditionally for the age range 20-49. Again, the data reveals very high adult male mortality among the Ingrian national minority during the first half of the 20th century - nearly one-third of those born in the 1920s lost their father before their 14th birthday. Perhaps even more strikingly, against the expected trend of declining mortality, the level of parental mortality increased for those born during the 1930 s with more than half experiencing the death of their father during childhood. In life table terms such levels of mortality translate into 50 percent of the male cohort dying within the age range of just fourteen years. Although less pronounced than in the male population, significant excess mortality also prevailed among Ingrian women. At the same time, adult mortality among the Russian national minority was about half the Ingrian level during the period in question.

The sharp increase referred to in the levels of parental mortality among the Ingrians born during the 1930s discounts the possibility of a delayed mortality transition. Nor can it be explained by population losses caused by military activities. This is clearly evident from the EPU survey and also supported by the comparison with the Polish FFS which suggests far lesser family disintegration in Poland, despite sustaining one of the highest war losses in Europe (Holzer and Kowalska 1997). As already noted, the main cause would appear to have been repressions over almost two decades. To this end it is important to note that these facts deserve attention not only from the historical point of view but also from today's perspective, since childhood experiences are well known to have a strong impact on the later lives of generations. As a task for future research, the longitudinal design of the survey offers a favorable basis to identify and analyze such enduring effects. Quite interestingly, the recent analysis 
based on the Estonian FFS has shown that in several domains, the impact of the parental home has strengthened across generations (Katus et al. 2002).

Figure 8. Adult male mortality. Ingrians and Estonians, birth cohorts 1924-1973.

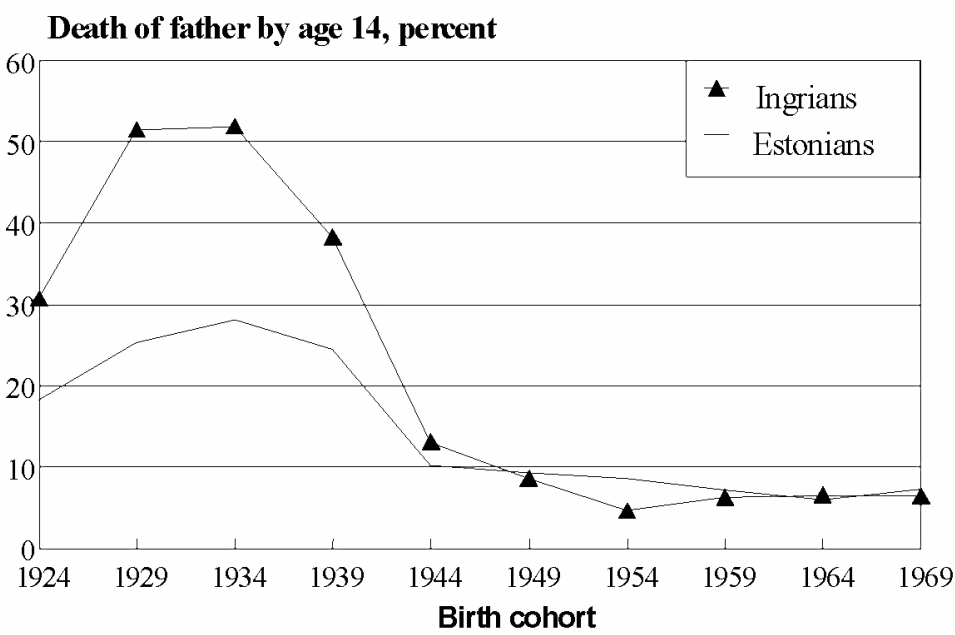

Source: authors' calculations, EPU \& EFFS

Although the levels of parental mortality of those born during the 1950 s and later seem to have declined and converged, this has occurred against a background of prolonged mortality stagnation for more than 35 years (Katus 2000; Katus and Puur 1992). This phenomenon - characterized by a persistently high and partly increasing mortality level, an extensive gender gap in life expectancy and other features - appears equally prevalent among the majority population as well as among national minorities in Estonia.

\section{Ethnic intermarriage}

The survey covered in detail partnership histories of the respondents but in this article the focus is limited to the ethnic homogeneity/heterogeneity of partnerships. Regarding national minorities, the family plays an essential role in transferring the minority identity from one generation to another, particularly when populations are small and/ or lack a compact settlement area. The maintenance of a minority identity is secured when both the mother and father belong to the same ethnic group, but may well involve a change of identity in mixed marriages when parents come from different backgrounds.

As revealed already in the previous sections, the proportion of mixed marriages among Ingrians is remarkably high. In the cohort range covered by the survey, on average of only eight percent of the unions have been contracted inside the national minority population. Ingrians have been most likely ( 51 percent) to marry Estonians, while 32 percent of the unions involve Russian partners and 9 percent partners from another 
ethnic background. Across the cohorts, the proportion of intra-group unions dropped from one-fifth in the case of those born in the 1920s and early 1930s to almost nil in the youngest generation. This development can be explained by the combination of relatively small numbers, a dispersed settlement pattern and a long tradition of mixed marriages already in the parental generation. To this end it must be noted that under Stalin's regime, a mixed marriage to a Russian or an Estonian offered a certain individual protection against the risk of deportation, particularly with respect to women.

In this respect, the development of the Ingrian national minority has appeared rather different from the Russians. Owing to their more compact and continuous pattern of settlement, the Russian national minority has displayed a much higher proportion of intra-group marriages. Close to two-thirds of the unions were contracted between ethnic Russians, one-fifth were with an Estonian partner and the remaining 14 percent with partners of other ethnic backgrounds (mostly Ukrainian and Belorussian) ${ }^{3 \cdot}$ Across cohorts, this pattern has been rather stable with only a slight increase in the prevalence of mixed marriages.

Regarding the future, the ethnic self-identification of children, reported in the survey by their mothers, shows that only about one-third of children born to Ingrian women explicitly identify with the minority population. The proportion of children who identified themselves as Estonians or Russians was closely correlated with the proportion of mixed marriages involving an Estonian or Russian partner.

\section{Language and religion}

The present section focuses on language and religious affiliation which yield information about the trends in the identity of the minority population over time. In the context of Estonia, particularly the importance of language, which has historically been the cornerstone of national identity for the majority population, should be underlined. In the survey, minority-specific characteristics were recorded not only with reference to the present situation of respondents but across generations and stages of the life cycle. Figure 9 (on next page) presents the usual language of the Ingrian national minority at the moment of the survey and two environments which are decisive from the viewpoint of socialization - the parental home and school. To draw attention to the major difference between the parental home, on one hand, and the language of education and the respondents' own household, on the other hand, the data on successive cohorts has been combined.

3 The pattern of prevailing intra-group marriage among the Russian national minority changes markedly if the distinction is made between the Russian national minority and postwar immigrants of the same ethnic background. 
Figure 9. Usual language. Ingrians, birth cohorts 1924-1973.

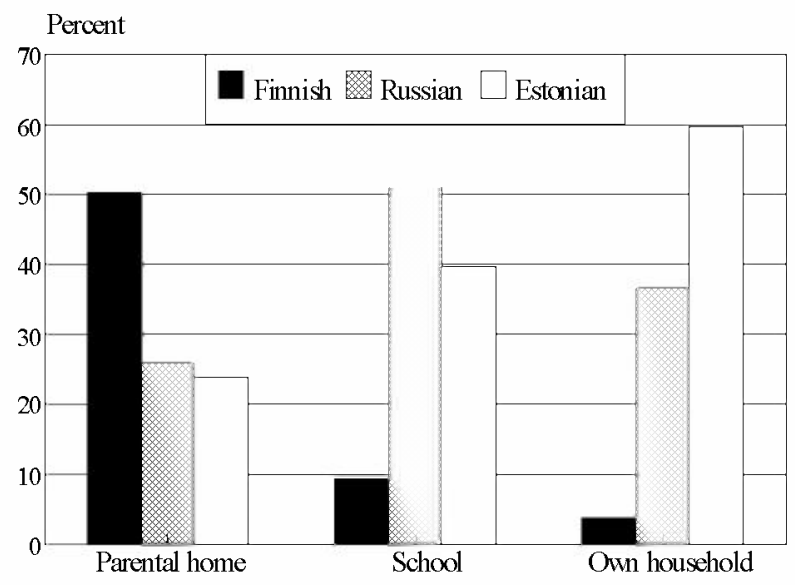

Source: authors' calculation, EPU.

In short, the analysis revealed a far-reaching erosion of the Finnish language during the lifetime of the cohorts covered by the survey. At the time of the survey, Finnish played only a marginal role with less than four percent of Ingrians speaking it regularly in the household. Finnish has been replaced either by Estonian or Russian - close to 60 percent of Ingrians had adopted Estonian as their usual language whereas slightly less than 40 percent had switched to Russian. Such a low level is in sharp contrast with the situation in the parental home where Finnish was still a prevailing language in nearly half of the cases. Of course, the almost total shift away from the mother tongue in just fifty years is hardly the result of the normal processes of development and relates directly to the Ingrians' loss of their homeland. The lack of an area of concentrated settlement within Estonia has also contributed to the process.

The observed pattern is principally different from the experience of the Russian national minority where there is only a minor decrease, mainly related to intermarriage with Estonians (Katus et al. 2000). The data on Ingrians also points to the fact that the school system has not supported the continuity of the Finnish language to any noticeable extent. On the contrary, the major shift towards Estonian or Russian has occurred namely at the stage of education, while the prevalence of Finnish at school and in the respondent's own household is quite similar. It is also interesting to note that among Ingrians, Russian has been most common as the language of education, but later in life Estonian has taken over its share by almost 20 percentage points. This general pattern is hardly surprising, but the survey allows one to follow the process from a cohort perspective, and adding the information on the parental generation extends the coverage back to the late 19th century (Figure 10). 
Figure 10. Finnish language at parental home and school. Ingrians, birth cohorts 1884-1973.

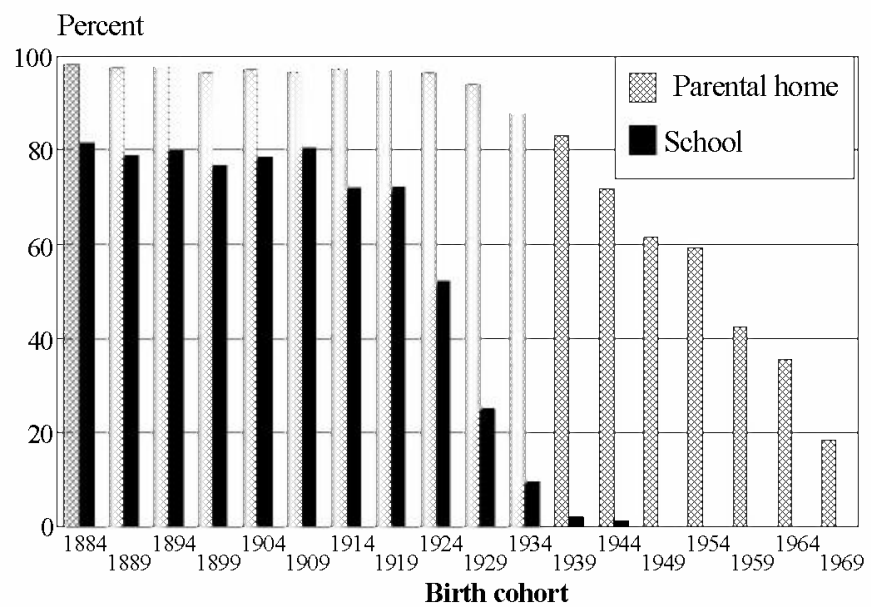

Source: authors' calculations, EPU.

In the cohorts born at the beginning of the century, Finnish was spoken as the common language of the parental home by well over 90 percent of the people - in other words, its position was quite comparable to the Estonian language among the majority population and the Russian language among the Russian national minority. The decline in the prevalence of Finnish took start in the cohorts born in the 1930s; however, in these cohorts its share still accounted for more than 80 percent. A glance at the graph shows that the erosion of Finnish in the parental home has been a relatively gradual process with no abrupt and dramatic changes. As the most common language spoken in the parental home, Finnish retained its position until the cohorts born in the early 1960s. In the youngest cohort covered by the survey, however, the prevalence of Finnish has dropped below 20 percent.

As regards the language of education, the prevalence of Finnish did not exceed 80 percent even in the cohorts born in the late 19th century. More importantly, however, the switch away from Finnish follows a clearly different pattern with respect to schooling. Its main characteristic is abruptness - in just 10-15 years the prevalence of Finnish dropped from 75 percent to less than 10 percent. Starting from the cohorts born in the late $1930 \mathrm{~s}$, education in the mother tongue was no longer available. This process was indeed rooted in the campaign against national minorities in Soviet Russia which began in the 1930s and involved the closing of all national schools, cultural and religious organizations (Kurs 1994). The corresponding effect was further strengthened by the dispersion of Ingrians in the 1940s which radically changed the socialization environment of the national minority. That compulsion was involved in this process is suggested by the fact that often the language of schooling was different not only from the language spoken in the parental home but also from the language used in later life. 
The design of the survey allows light to be shed on various factors which have contributed to the change in language, and further, affected the choice between Estonian and Russian. The survey also supplied information about the knowledge and usage of other languages. Thus, slightly more than a quarter of the Ingrian minority used more than one language in their household. This involved basically three combinations of languages: Estonian and Finnish ( 6 percent), Russian and Finnish (5 percent), Estonian and Russian (20 percent). Unlike the immigrant population, Ingrians, as well as Russians belonging to the national minority, featured a widespread knowledge of Estonian (over 90 percent). On the other hand, according to the 1989 census, only about 15 percent of the foreign-born reported a knowledge of Estonian (Katus and Sakkeus 1993). Even if underreported, such an extensive gap in Estonian language proficiency points to a very different degree of societal integration among national minorities and the foreign-origin population.

Apart from the language, the religious affiliation of the Ingrian national minority has undergone a somewhat lesser change. At the time of the survey, almost three-quarters of the Ingrian minority considered themselves Lutheran, with less than 20 percent belonging to the Orthodox and 8 percent to other traditions. In the parental generation the proportion of Lutherans was close to 80 percent, with other affiliations correspondingly less represented. The shift away from the Lutheran tradition can be easily seen from the cohort perspective (Figure 11). The analysis revealed that in the cohorts born in 1920s still close to 90 percent were Lutheran, whereas by the 1960s and 1970s generation this proportion had dropped to under two-thirds. In the latter cohorts, nearly one-third of the Ingrians regarded themselves as Orthodox. The shift in religious affiliation closely mirrors similar trends in the language spoken: being Lutheran is virtually synonymous with speaking Estonian as the usual language, whereas being Orthodox implies about an 85-percent chance of switching to Russian.

Figure 11. Religious affiliation. Ingrians, birth cohorts 1924-1973.

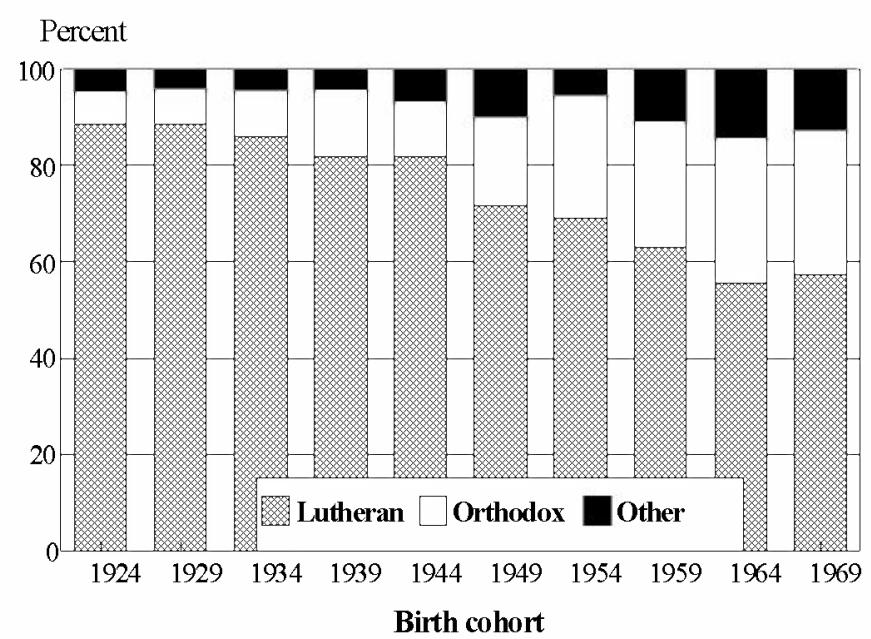

Source: authors' calculations, EPU. 
To this end it is interesting to add that the distinction according to religion/language characteristics refers to noticeable heterogeneity within the Ingrian population itself. For example, regarding economic characteristics the unemployment rate among Ingrians of the Lutheran faith was not significantly different from the corresponding figure of Estonians, whereas joblessness among the Orthodox segment turned to be much higher, close to the levels found among the immigrant population.

\section{Summary and discussion}

The article outlines the demographic development of the Ingrian national minority in Estonia. Reconstructed from a recently conducted event history survey, a demographic account of the Ingrian minority in the case of Estonia is provided for the first time.

The analysis revealed a clearly distinct profile of the Ingrian national minority with respect to most processes and characteristics under investigation. As regards population size, the estimates based on census and vital statistics revealed a marked discrepancy. The more than twofold difference in the number of Ingrians, however, underlines the decisive importance of definitions in the study of national minorities rather than an imperfect estimation procedure. Another important feature of the Ingrian minority proved to be the highly irregular nature of their age structure. Against the background of the majority population, in relative terms the largest concentration of Ingrians was found in the birth cohorts of the 1920s which primarily reflects the arrival of the minority in Estonia in the aftermath of the Second World War. In the war years, the Ingrian cohorts were nearly halved, but more interestingly, an almost similar sharp decrease was repeated in 1946-1947. In the cohorts born since the 1950s, census statistics reveal a further decline in the number of Ingrians, however, this tendency cannot be explained by any demographic process but reflects the shift in ethnic selfidentification and a tendency towards assimilation.

Systematic differences were observed also with respect to major demographic processes. In contrast to Estonians who completely missed the postwar baby boom, Ingrians experienced a certain increase of fertility in the second half of the 1950s when societal conditions started to normalize. As a result of divergent trends, from the early 1970s up to the beginning of the 1990s, however, Ingrians featured systematically lower fertility levels compared to the majority population. At the same time, Ingrians have been characterized by an earlier start of childbearing and a somewhat lower proportion of extramarital births than Estonians. Regarding mortality, the Ingrian minority has shown consistently lower survival rates, both with respect to infants, children and the adult population. Reflecting extremely harsh societal conditions, excess mortality was particularly pronounced until the end of the $1950 \mathrm{~s}$. In that period the mortality level of the Ingrians was almost twice as high as that of the Estonians, who also suffered heavily from Stalin's repressions. 
The marriage pattern of the Ingrian national minority has been shaped by a noticeably high incidence of ethnic intermarriage. In the cohorts under investigation, less than one-tenth of all marriages have been contracted within the minority population, and in the younger generations ethnic intermarriage has dropped to almost nil. With regard to minority characteristics, the analysis revealed a far-reaching erosion of the Finnish language among the Ingrians in Estonia. By the time of the survey, less than four percent of the Ingrians still spoke Finnish in their household. Although expressed to a lesser extent, a parallel shift away from the Lutheran tradition was observed in the religious affiliation of the Ingrian national minority. Regarding the future, the lack of a compact settlement area and the trends in ethnic intermarriage, language and ethnic self-identification predict the continuation of assimilation of the Ingrians in Estonia, initiated by the loss of their historical homeland.

The study could be further extended in at least two major directions. To allow a comparative perspective, similar analyses are recommended for the Ingrians in their historical homeland in St.Petersburg Oblast and in Finland. Among others, this would allow an examination of the role and impact of varying societal contexts on the development of a national minority population. Regarding Finland, the selectivity of the migration of Ingrians from Estonia to Finland could form an issue of separate scholarly interest. The material of the EPU survey offers a favorable basis for comparative research, assuming the availability of corresponding datasets in other countries. The second direction of future research could involve the in-depth analysis of the survey focusing, among others, on specific processes and factors which have contributed to the continuity/loss of minority identity across generations.

\section{References}

Ahven, Andri. 1998. Kuritegevus ja turvatunne. Sotsiaaltrendid. Tallinn: Eesti Statistikaamet, lk. 84-90.

Aman, Viktor. 1961. Estlanssvenskarna under andra världskriget. Överflyttningen till Sverige. In: En bok om Estlands svenskar, edited by E. Nyman. Stockholm.

Angelus, Oskar. 1995. Tuhande valitseja maa. Mälestusi Saksa okupatsiooni ajast 1941-1944. Tallinn: Olion.

Arens, Ilmar. 1994. Peipsitagused eestlased. Tartu: Tartu Ülikooli Kirjastus.

Blossfeld, Hans-Peter and Götz Rohwer. 1995. Techniques of event history modeling. New approaches to causal analysis. Mahwav: Lawrence Erlbaum Associates Publishers.

Blumfeldt, Evald. 1961. Estlandssvenskarnas historia. In: En bok om Estlands svenskar, edited by E.Nyman. Stockholm.

Carrére d'Encausse, Hèléne. 1982. Decline of the empire. The Soviet socialist republics in revolt. NewYork: Newsweek Books.

Council of Europe. 1993-2001. Recent demographic developments in Europe. Strasbourg: Council of Europe.

EKDK. 1992a. Eesti regionaalne rahvastikuandmete pank I. RU sari A, nr.29. Tallinn: EKDK. EKDK. 1992b. Eesti regionaalne rahvastikuandmete pank II. RU sari A, nr. 31. Tallinn: EKDK. 
EKDK. 1995a. Eesti Pere-ja Sündimusuuring. Metodoloogiaülevaade. RU sari A, nr. 39. Tallinn: EKDK.

EKDK. 1995b. Eesti Pere- ja Sündimusuuring. Standardtabelid. RU sari C, nr. 6. Tallinn: EKDK.

EKDK. 1999. Eesti Pere-ja Sündimusuuring. Meesküsitluse metodoloogiaulevaade. RU sari A, nr. 40. Tallinn: EKDK.

EKDK. 2003. Eesti rahvastiku ühtlusarvutatud sünniandmed 1959-1970. RU sari C, nr. 16. Tallinn: EKDK. Forthcoming.

Festy, Patrick. 1984. Fertility in Western Countries from 1870 to 1970. Bangkok: United Nations.

Goskomstat. 1990. Natsionalnyi sostav naselenia RSFSR. Moscow: Goskomstat RSFSR.

Grass, Konrad. 1914. Die Russische Sekte. Dorpat.

Gurin, Samuel. 1936. Juudi vähemusrahvuse statistika Eestis. Tallinn: Juudi Kultuurvalitsus.

Hasselblatt, Werner. 1928. Zehn Jahre deutsch-baltischer Politik in Estland. Jahrbuch des baltischen Deutschteums in Lettland und Estland, 1929. Riga, pp. 66-70.

Haug, Werner, Youssef Courbage and Paul Compton (ed.). 1999-2001. The demographic characteristics of national minorities in certain European states. Strasbourg: Council of Europe.

Haug, Werner, Youssef Courbage and Paul Compton (editors). 2002. Immigrant populations in Europe. Strasbourg: Council of Europe. Forthcoming.

Hehn, von Jürgen. 1982. Die Umsiedlung der baltischen Deutschen - das letzte Kapitel baltischdeutscher Geschichte. Marburd/Lahn: Herder Institut.

Holzer, Jerzy and Irena Kowalska. 1997. Poland. Standard country report. Fertility and family surveys in countries of the ECE region. New York and Geneva: United Nations.

Katus, Kalev. 1990. Demographic development in Estonia through centuries. Yearbook of Population Research in Finland 28, pp. 50-67. Helsinki: The Population Research Institute, The Family Federation of Finland.

Katus, Kalev. 2000. Long-term mortality trend in Baltic countries. Trames, vol.4, no. 3 (Special Issue on Estonian Population), pp. 231-256.

Katus, Kalev and Allan Puur. 1992. Eesti rahvastiku suremustrend elutabelite analüüsi põhjal. RU sari B, no. 14. Tallinn: EKDK.

Katus, Kalev, Allan Puur, Asta Põldma and Luule Sakkeus. 1999. Rahvastikuvananemine Eestis. RU sari D, nr. 1. Tallinn: EKDK.

Katus, Kalev, Allan Puur and Asta Põldma. 2002. Eesti põlvkondlik rahvastikuareng. RU sari D, nr. 2. Tallinn: EKDK.

Katus, Kalev, Allan Puur and Luule Sakkeus. 1997. Development of national minorities. Republic of Estonia up to 1944. Trames, vol.1, no. 3 (Special Issue on Estonian Population), pp. 221246 .

Katus, Kalev, Allan Puur and Luule Sakkeus. 2000. Development of national minorities in Estonia. In: The demographic characteristics of national minorities in certain European states, edited by W. Haug, Y. Courbage and P. Compton. Strasbourg: Council of Europe, pp. $29-92$.

Katus, Kalev and Luule Sakkeus. 1993. Foreign-born population in Estonia. RU series B, no. 19. Tallinn: EKDK.

Kasmel, Anu, Andrus Lipand, Katre Kasmel, Uno Traat, Anna Markina, Antti Uutela, Satu Helakorpi and Pekka Puska. 1997. Eesti täiskasvanud elanikkonna tervisekäitumise uuring, kevad 1996. Helsinki: Kansanterveyslaitos.

Kaufmann, Voldemar. 1967. Rahvastiku dünaamika ja seda mõjutanud seaduspärasused Eestis XX sajandi esimesel poolel. 1897-1959. Tallinn. Manuscript.

Kommitten för Estlanssvenskarna. 1950. Redogörelse för dess verksamhet 1940-1950. Stockholm.

Konstitutsija SSSR. 1977. Moscow: Politizdat.

Kurs, Ott. 1994. Ingeria: The broken landbridge between Estonia and Finland. GeoJournal, vol. 33 , no. 1, pp. 107-113. 
Kyntäjä, Eve. 1997. Ethnic remigration from the former Soviet Union to Finland - patterns of ethnic identity and acculturation among the Ingrian Finns. Yearbook of Population Research in Finland, vol.34, pp. 102-113. Helsinki: The Population Research Institute, The Family Federation of Finland.

Loov-Gurin, Eugenia. 1990. Juudid Eestis. Tallinn: Juudi Kultuuri Selts.

Loov-Gurin, Eugenia. 1994. Holocaust of Estonian Jews 1941. Tallinn: Eesti Juudi Kogukond.

Misiunas, Romuald and Rein Taagepera. 1983. The Baltic states. Years of dependence 19401980. Berkeley: University of California Press (333 pp).

Misiunas, Romuald and Rein Taagepera. 1993. The Baltic states. Years of dependence 19401990. London: Hurst and Co. (400 pp).

Moora, Aliise. 1964. Peipsimaa etnilisest ajaloost. Tallinn: Eesti Riiklik Kirjastus.

Nigol, August. 1918. Eesti asundused ja asupaigad Wenemaal. Tartu: Postimees.

Notkola, Irma-Leena. 1989. Luonnollisesta hedelmällisyydestä lapsirajoitukseen. Kuopio: Finnish Demographic Society.

Palli, Heldur. 1996. Eesti rahvastiku ajalugu aastani 1712. Tallinn: Teaduste Akadeemia Kirjastus.

Pavelson, Marje. 1997. Mitte-eestlased Eesti tööturul. In: Vene noored Eestis - sotsioloogiline mosaiik, edited by P.Järve. Tartu: Tartu Ülikool, lk.183-195.

Pullat, Raimo. 1981. Peterburi eestlased. Tallinn: Valgus.

Riigi Teataja. 1925. No.31/32. Tallinn.

Sakkeus, Luule. 1996. Estonia. In: International migration in Central and Eastern Europe and the Commonwealth of Independent States, edited by T. Freijka. New York and Geneva: United Nations, pp. 57-67.

Sakkeus, Luule. 2000. Demographic behaviour patterns of immigrants and national minority of the same ethnic background: the case of Estonia. Trames, vol.4, no.3 (Special Issue on Estonian Population), pp. 268-285.

Salo, Vello. 1993. Deported in 1941. General index of deportees from Estonia. Brampton: Maarjamaa.

Sardon, Jean-Paul and Gerard Calot. 1997. La reprise de la fécondité au mileu des années 1930, phénomène non perçu des observateurs du temps? L'Observatoire Démographique Européen. No. 5.

Schiemann, Peter. 1937. Ein europäisches Problem. Unabhängige Betrachtungen zur Minderheitenfrage. Wien/Leipzig.

Stepanjan A. 1981. Sovetskii narod-stroitel kommunizma. Moskva: Nauka.

TsSK. 1905. Pervaja vserossiiskaja perepis naselenija Rossiiskoi Imperii $1897 \mathrm{~g}$. St. Peterburgskaja gubernia. St. Petersburg.

TsSK. 1928. Vsesojuznaja perepis 17. dekabrja 1926. Narodnost i rodnoi jazyk naselenija SSSR. Vol. IV. Moscow.

UNECE. 2000. Fertility and Family Surveys in countries of the ECE region. Standard country report. Estonia. New York and Geneva: United Nations.

Veispak, Teet. 1986. Naselenie goroda Revelja v konce XVII-nachale XVIII vv. Tallinn.

Viikberg, Jüri (ed.). 1999. Eesti rahvuste raamat. Rahvusvähemused, rühmad ja killud. Tallinn: Eesti Entsüklopeediakirjastus.

Vishnevski, Anatoli and Andrei Volkov (eds.). 1983. Vosproizvodstvo naselenia SSSR. Moscow.

Willekens, Frans. 1999. The life course: models and analysis. In: Population issues: an interdisciplinary focus, edited by P. Dykstra and L. van Wissen. Dordrecht: Kluwer Academic/ Plenum Publishers, pp.23-52.

Wittram, Reinhard. 1973. Baltische Geschichte. Die Ostseelande Livland, Estland, Kurland 11801918. Grundzüge und Durchblicke. Darmstadt.

Zelinski, Wilbur. 1971. The hypothesis of mobility transition. Geographical Review, vol. 61, no. 2, pp. 219-249. 